\title{
Ampulla of Vater Cancer Pathologic Distant Metastasis TNM Finding v8
}

National Cancer Institute

\section{Source}

National Cancer Institute. Ampulla of Vater Cancer Pathologic Distant Metastasis TNM

Finding v8. NCI Thesaurus. Code C134843.

A pathologic finding about one or more characteristics of ampulla of Vater cancer, following the rules of the TNM AJCC v8 classification system as they pertain to distant metastases. 